Urbanek P., Programy partycypacji we wtasności jako narzędzie polityki wynagradzania kadry kierowniczej na przykładzie banków publicznych w Polsce, „Economics and Law”, Polszakiewicz B., Boehlke J. (ed.), Vol. 13, No. 1/2014, pp. 225-238. DOI: http://dx.doi.org/10.12775/ EiP.2014.017.

\title{
PROGRAMY PARTYCYPACJI WE WŁASNOŚCI JAKO NARZĘDZIE POLITYKI WYNAGRADZANIA KADRY KIEROWNICZEJ NA PRZYKŁADZIE BANKÓW PUBLICZNYCH W POLSCE ${ }^{\diamond}$
}

\section{STRESZCZENIE}

Długoterminowe programy motywacyjne oparte na własności są jednym z powszechnie wykorzystywanych narzędzi polityka wynagradzania kadry kierowniczej instytucji sektora finansowego. Jest to rozwiązanie, które zgodnie $\mathrm{z}$ tezami formułowanymi na gruncie teorii agencji, ma łagodzić problem agencji i konflikt interesów między menedżerami i akcjonariuszami. Doświadczenia ostatniego kryzysu finansowego pokazują, iż szerokie zastosowanie tego rodzaju narzędzi motywacyjnych w czołowych bankach amerykańskich nie uchroniło tych instytucji i ich akcjonariuszy przed drastycznymi stratami.

W artykule podjęta została próba ocena programów partycypacji menedżerów we własności stosowanych w bankach publicznych w Polsce. W szczególności wskazano na rodzaj stosowanych rozwiązań, ich wpływ na wyniki finansowe i ryzyko działalności operacyjnej banków, udział korzyści osiąganych przez menedżerów z tego tytułu w całkowitych wynagrodzeniach.

Słowa kluczowe: polityka wynagradzania, sektor bankowy, banki publiczne w Polsce Klasyfikacja JEL: G21, G23

Piotr Urbanek, Uniwersytet Łódzki, Wydział Ekonomiczno-Socjologiczny, Katedra Ekonomii Instytucjonalnej, 90-255 Łódź, ul. Rewolucji 1905 r. 412, tel.: +48 42635 5161, e-mail: piotrur@uni.lodz.pl.

Artykuł powstał dzięki finansowemu wsparciu badań naukowych przez Narodowe Centrum Nauki na mocy decyzji DEC-2011/03/B/HS4/04814. 


\title{
LONG-TERM INCENTIVES PLANS AS AN INSTRUMENT OF EXECUTIVES' COMPENSATION POLICY IN PUBLIC BANKS IN POLAND
}

\author{
SUMMARY
}

Long-term incentives plans (LTIPs) are one of the commonly used tools of top executive's compensation policy in financial sector institutions. It is a solution which, in accordance with theses formulated on the basis of agency theory, can solve the agency problem and manage conflicts of interest between managers and shareholders. The experience of the recent financial crisis has shown that extensive use of this type of instruments in leading U.S. banks did not protect these institutions and their shareholders from the catastrophic losses.

This paper evaluates such incentives programs in public banks in Poland. In particular, it demonstrates the types of LTIPs, their impact on the financial and operational risks, and the share of the managers' compensation resulting from such programs in total compensation.

Keywords: compensation policy, banking sector, public banks in Poland

JEL Classification: G21, G23

\section{WSTĘP}

Polityka wynagradzania kadry kierowniczej instytucji sektora finansowego jest traktowana, jako jeden z kluczowych czynników, który doprowadził do obecnego kryzysu finansowego. W licznych badaniach empirycznych były podejmowane próby identyfikacji czynników determinujących poziom i strukturę wynagrodzeń osób zarządzających bankami w okresie przed i w trakcie ostatniego kryzysu finansowego.

Jedną z kwestii, które są szczególnie silnie akcentowane w badaniach empirycznych poświęconych tej problematyce jest zjawisko, które można określić terminem „Kultury Własności”. Wysocy funkcjonariusze banków, będąc właścicielami znaczących pakietów akcji w kierowanych przez nich instytucjach są narażeni na podobne ryzyko co inni akcjonariusze. Jest to rozwiązanie, które zgodnie $z$ tezami formułowanymi na gruncie teorii agencji, ma łagodzić problem agencji i konflikt interesów między menedżerami i akcjonariuszami. Doświadczenia ostatniego kryzysu finansowego pokazują, iż szerokie zastosowanie tego rodzaju narzędzi motywacyjnych w czołowych bankach amerykańskich nie uchroniło tych instytucji i ich akcjonariuszy przed drastycznymi stratami. 
W tym kontekście interesujące wydaje się dokonanie analizy skali i skutków stosowania tego rodzaju narzędzi w polskim sektorze bankowym. Celem artykułu jest ocena programów partycypacji menedżerów we własności stosowanych w bankach publicznych w Polsce. W szczególności chodzi o rodzaj stosowanych rozwiązań, udział korzyści osiąganych przez menedżerów z tego tytułu w całkowitych wynagrodzeniach, ich wpływ na wyniki finansowe i ryzyko działalności operacyjnej banków.

\section{KONTRAKT OPARTY NA WYNIKACH JAKO MECHANIZM ROZWIAZZYWANIA PROBLEMU AGENCJI W SEKTORZE BANKOWYM}

Teoretyczną perspektywą badawczą, która jest bardzo często stosowana do analizy zasad wynagradzania kadry menedżerskiej jest tzw. relacja agencji. Jest ona skutkiem oddzielenia własności korporacji od kontroli nad korporacją. Relację agencji można zdefiniować jako kontrakt, w którym jedna ze stron (pryncypał) angażuje drugą stronę (agenta) do świadczenia usług w swoim imieniu, co pociąga za sobą delegację części uprawnień decyzyjnych na agenta ${ }^{1}$. Jeżeli obie strony kontraktu dążą do maksymalizacji własnych korzyści i zarazem posiadają sprzeczne cele i dążenia pojawia się zagrożenie wystąpienia oportunistycznych postaw agenta, który może podejmować działania nie zgodne $z$ oczekiwaniami pryncypała. W tej sytuacji kluczowe staje określenie mechanizmów, które zmniejszałoby konflikt interesów między pryncypałem i agentem.

Można wskazać dwa mechanizmy, za pomocą których pryncypał może nadzorować agenta. Pierwszym z nich jest bezpośredni monitoring, polegający na tworzeniu systemu umożliwiającego zbieranie informacji służących do śledzenia zachowań agenta. Drugim mechanizmem jest kontrakt oparty na wynikach. Istotą tego rozwiązania jest to, iż korzyści osiągane przez agenta i pryncypała zależą od tego samego rodzaju działań. Taki kontrakt powoduje, że agent jest skłonny zachowywać się zgodnie z interesem pryncypała.

Kluczową kwestią przy określaniu zasad konstrukcji optymalnych relacji kontraktowych, jest związek występujący między wynagrodzeniami kadry kierowniczej a wynikami ekonomicznymi. Powiązanie poziomu wynagrodzenia $\mathrm{z}$ wynikami jest rozwiązaniem, które zbliża preferencje menedżerów i akcjonariuszy. Powinno to oznaczać, że wzrost korzyści osiąganych przez akcjo-

${ }^{1}$ M.C. Jensen, W.H. Meckling, Theory of the Firm: Managerial Behavior, Agency Costs and Ownership Structure, „Journal of Financial Economics”, No 3/1976, p. 308. 
nariuszy prowadzi do wzrostu wynagrodzeń menedżerów, kiedy akcjonariusze tracą przekłada się to spadek wynagrodzeń. Warunkiem skuteczności takich kontraktów jest zwiększenie w strukturze wynagrodzenia udziału zmiennych składników - premii za wyniki, oraz stosowanie programów partycypacji menedżerów we własności, w tym opcji na akcje i bezpłatnego przydziału akcji. Większy udział tego rodzaju komponentów w pakiecie wynagrodzenia motywuje menedżerów do podejmowania bardziej ryzykownych decyzji prowadzących do poprawy wyników ekonomicznych.

Działalność biznesowa w sektorze bankowym ma swoją specyfikę, która wymaga innego podejścia do rozwiązywania problemu agencji, niż ma to miejsce $\mathrm{w}$ innych sektorach gospodarki. $\mathrm{Na}$ tę specyfikę składa się wiele czynników²: ryzyko systemowe, skala i charakter prowadzonych operacji, powiązania między podmiotami sektora finansowego, innowacyjne instrumenty finansowe, skomplikowane struktury własnościowo-kontrolne wielkich grup finansowych, szybkie zmiany modeli biznesowych instytucji finansowych. Problem agencji, który oddaje istotę konfliktów interesów między różnymi podmiotami związanymi z działalnością korporacji i który determinuje rodzaj instrumentów nadzoru korporacyjnego, w przypadku banków jest bardziej skomplikowany. Pojawia się tutaj nowa oś konfliktu wynikająca $z$ rozbieżności preferencji na linii akcjonariusze-deponenci ${ }^{3}$. Interesy tych ostatnich są związane ze zobowiązaniami banków. Kluczowe dla nich jest bezpieczeństwo ich lokat, czyli są oni zainteresowani stabilnością banku w długiej perspektywie, a nie tak jak akcjonariuszy maksymalizacją wyników finansowych, co wymaga akceptacji wysokiego poziomu ryzyka.

Specyfika działalności bankowej może mieć daleko idące implikacje jeśli chodzi o politykę wynagradzania kadry kierowniczej. Kontrakt oparty na wynikach przestaje być najważniejszym mechanizmem zbliżającym preferencje akcjonariuszy i menedżerów. Jeżeli ochrona interesów deponentów jest równie ważna jak akcjonariuszy, optymalna struktura pakietu wynagrodzenia menedżerów w wysoce lewarowanych instytucjach finansowych powinna charakteryzować się mniejszą wrażliwością wynagrodzeń na wyniki ${ }^{4}$ Konsekwencją tego powinien być mniejszy zakres stosowania w bankach niż w innych sektorach programów motywowania opartych na własności.

2 M. Marcinkowska, Jak wzmocnić wtadztwo korporacyjne w bankach?, [w:] P. Urbanek (red.), Nadzór korporacyjny w warunkach kryzysu gospodarczego, Wydawnictwo Uniwersytetu Łódzkiego, Łódź 2010, s. 154.

${ }^{3}$ P.O. Mulbert, Corporate governance of banks after the financial crisis - Theory, evidence, reforms, CEGI Working Paper Series in Law, No. 151/2010, p. 15.

${ }^{4} \mathrm{~J}$. Kose, Q. Yiming, Incentive Features in CEO Compensation in the Banking Industry, „Economic Policy Review", April 2003, p. 110. 


\section{PROGRAMY PARTYCYPACJI WE WŁASNOŚCI KADRY KIEROWNICZEJ BANKÓW W POLSCE W ŚWIETLE REGULACJI PRAWNYCH}

W Polsce do roku 2012 spółki publiczne, w tym również banki notowane na GPW w Warszawie nie miały obowiązku stosowania długoterminowych programów motywacyjnych opartych na własności. Spółki, które sięgały do tego rozwiązania musiały $\mathrm{w}$ raporcie rocznym ujawnić „... wartość wynagrodzeń, nagród lub korzyści, w tym wynikających z programów motywacyjnych lub premiowych opartych na kapitale emitenta, w tym programów opartych na obligacjach $\mathrm{z}$ prawem pierwszeństwa, zamiennych, warrantach subskrypcyjnych (w pieniądzu, naturze lub jakiejkolwiek innej formie)..." Dodatkowo wycena usług opłacanych w tej formie powinna być dokonywana zgodnie z zasadami określonymi w Międzynarodowych Standardach Sprawozdawczości Finansowej ${ }^{6}$.

Specyfika polityki wynagradzania kadry kierowniczej w sektorze bankowym oraz jej dysfunkcjonalności ujawnione przez obecny kryzys finansowy wykazały potrzebę przeprowadzenia głębokiej reformy. Prace te miały charakter zmian legislacyjnych wprowadzanych na szczeblu narodowym. Pojawiły się także liczne ponadnarodowe inicjatywy regulacyjne takich instytucji międzynarodowych jak G20, Rada Stabilności Finansowej, Europejski Komitet Nadzoru Bankowego, Komisja Europejska. Z tych ostatnich największy wpływ na ład prawny obowiązujący w polskim sektorze bankowym mają działania podejmowane przez Komisję Europejską oraz Parlament Europejski.

W kwietniu 2009 roku Komisja Europejska wydała zalecenie związane $\mathrm{z}$ polityką wynagradzania, w którym szczególny nacisk kładzie się na procedury ustalania polityki wynagradzania w sektorze usług finansowych ${ }^{7}$. W Zaleceniu 384 pojawiła się rekomendacja związana z zasadami wypłaty wynagrodzenia zmiennego. W przypadku przyznania znacznej premii wypłata większej jej części powinna zostać odroczona na pewien minimalny okres. Odroczona część premii może składać się m.in. z akcji, udziałów, opcji.

\footnotetext{
${ }_{5}^{5}$ Rozporzadzeniu Ministra Finansów z dnia 19 lutego 2009 r. w sprawie informacji bieżacych i okresowych przekazywanych przez emitentów papierów wartościowych oraz warunków uznawania za równoważne informacji wymaganych przepisami prawa państwa niebędacego państwem cztonkowskim, Dz. U. 2009 Nr. 33, poz. 259, § 91.1, pkt. 17.

${ }^{6}$ Międzynarodowy Standard Sprawozdawczości Finansowej 2, Ptatnosici w formie akcji wtasnych.

7 Zalecenie Komisji z dnia 30 kwietnia 2009 r. w sprawie polityki wynagrodzeń w sektorze ustug finansowych 2009/384/WE, Dz.U. UE L 120/22.
} 
Banki powinny ujawniać informacje na temat kryteriów wynikowych stanowiących podstawę uprawnień do akcji, opcji na akcje lub zmiennych składników wynagrodzeń.

Rok po przyjęciu opisanych wyżej zaleceń Komisja Europejska dokonała oceny zakresu, w jakim kraje członkowskie wprowadziły w życie te rozwiązania $^{8}$. Zaledwie szesnaście państw członkowskich zastosowało w części lub całkowicie zalecenia Komisji, kolejne pięć rozpoczęło ich wprowadzanie. Sześć państw, w tym Polska, nie podjęło żadnych działań. W tej sytuacji zdecydowano, że zalecenia te zostaną włączone do znowelizowanej Dyrektywy Unii Europejskiej z 2006 roku w sprawie wymogów kapitałowych - CDR III ${ }^{9}$. Celem tej inicjatywy było m.in. przełożenie zasad zawartych w Zaleceniu 384 na unijne wymogi prawne.

Postanowienie Dyrektywy CRD III rozszerzają i precyzują zasady polityki wynagrodzeń z Zalecenia 384, w tym te, które odnoszą się do długoterminowych programów motywacyjnych opartych na własności. Wypłata znacznej części wynagrodzenia zmiennego (40-60\%) powinna być rozłożona w czasie na okres nie krótszy niż 3 do 5 lat i przyjmować formę akcji albo innych instrumentów niegotówkowych (co najmniej 50\%).

W odpowiedzi na Dyrektywę CRD III Parlamentu Europejskiego Sejm przyjął Ustawę z dnia 28 kwietnia 2011 roku $^{10}$. Celem jej uchwalenia było między innymi dostosowanie polskich przepisów dotyczących sektora finansowego do międzynarodowych regulacji związanych z polityką wynagradzania. Ustawa zobowiązuje banki do przestrzegania zasad ustalania zmiennych składników wynagrodzeń zarządu, utworzonych w drodze uchwały przez Komisję Nadzoru Finansowego. W październiku 2011 roku Komisji Nadzoru Finansowego wydała uchwałę w sprawie szczegółowych zasad funkcjonowania systemu zarządzania ryzykiem i systemu kontroli wewnętrznej oraz szczegółowych warunków szacowania przez banki kapitału wewnętrznego i dokonywania przeglądów procesu szacowania i utrzymywania kapitału wewnętrznego oraz zasad ustalania polityki zmiennych składników wynagrodzeń osób zajmujących stanowiska kierownicze w banku ${ }^{11}$.

${ }^{8}$ Komisja Europejska, Zielona ksiega. Ead korporacyjny w instytucjach finansowych oraz polityka wynagrodzen, Bruksela 2010.

9 Directive 2010/76/EU of the European Parliament and of the Council of 24 November 2010 amending directives 2006/48/EC and 2006/49/EC as regards capital requirements for the trading book and for re-securitisations, and the supervisory review of remuneration policies, Dz. U. UE L 329/3/2010.

10 Ustawa z dnia 28 kwietnia 2011 roku z zmianie ustawy - Prawo bankowe, ustawy o obrocie instrumentami finansowymi oraz ustawy o nadzorze nad runkiem finansowym, Dz. U. z $2011 \mathrm{r}$. $\mathrm{Nr}$ 131, poz. 763.

11 Uchwata Komisji Nadzoru Finansowego z dnia 4 pazdziernika 2011 roku w sprawie szczegótowych zasad funkcjonowania systemu zarządzania ryzykiem i systemu kontroli wewnętrznej 
W Uchwale poruszona została kwestia programów partycypacji we własności. Aby zachęcić kadrę kierowniczą banku do działań uwzględniających długookresowo dobro spółki $\mathbf{5 0 \%}$ wynagrodzenia zmiennego powinny stanowić akcje lub odpowiadające im tytuły własności, a także składniki zaliczane do funduszy podstawowych banku.

\section{WYNIKI BADAŃ}

Ocena programów partycypacji we własności osób zarządzających została przeprowadzona na próbie 16 banków notowanych na Giełdzie Papierów Wartościowych w Warszawie. Dane do analizy zostały zebrane z raportów rocznych banków publicznych dla lat 2008-2012. Jest to okres, w którym występowały istotne różnice, jeśli chodzi o koniunkturę gospodarczą i poziom indeksów giełdowych. Dwa pierwsze lata objęte badaniem to okres bezprecedensowej bessy na rynku kapitałowym, kolejne trzy lata charakteryzowały się stopniową odbudową poniesionych wcześniej strat. Biorąc pod uwagę przedstawione $\mathrm{w}$ poprzednim punkcie przepisy odnoszące się do polityki wynagradzania kadry kierowniczej banków, stosowane przed 2012 rokiem programy partycypacji we własności nie wynikały z konieczności stosowania zapisów Uchwały KNF, lecz były elementem autonomicznej polityki wynagradzania przyjętej przez każdy z banków.

W tabeli 1. przedstawiona została krótka charakterystyka programów motywowania kadry kierowniczej w polskich bankach publicznych. Na 16 badanych banków tego rodzaju rozwiązania są stosowane w dziesięciu bankach. Należy podkreślić, że tylko w trzech bankach są to programy oparte na kapitale emitenta, w dwóch kolejnych dodatkowo występują programy w ramach grupy kapitałowej, natomiast pięć banków stosuje tylko programy oferujące kadrze kierowniczej opcje na akcje i akcje banku dominującego. Ten ostatni przypadek jest sprzeczny z nadrzędnym celem takich programów, którym jest zachęta do szczególnej dbałości o dobro banku. Bodźcem do takich zachowań powinna być wypłata części wynagrodzenia w akcjach i odpowiadającym im instrumentom własności banku, w którym osoba wynagradzana pełni funkcje kierownicze. Jednoznacznie wskazuje na to interpretacja Uchwały Komisji Nadzoru Finansowego ${ }^{12}$.

oraz szczegótowych warunków szacowania przez banki kapitatu wewnętrznego i dokonywania przegladów procesu szacowania i utrzymywania kapitatu wewnętrznego oraz zasad ustalania polityki zmiennych sktadników wynagrodzeń osób zajmujących stanowiska kierownicze w banku, $\mathrm{Nr}$ 258/2011.

12 Komisja Nadzoru Finansowego, Interpretacja uchwat KNF w zakresie polityki zmiennych sktadników wynagrodzeń osób zajmujących stanowiska kierownicze w banku, 23.12.2011. 
Tabela 1. Charakterystyka długoterminowych programów motywacyjnych w bankach publicznych w Polsce

\begin{tabular}{|c|c|c|}
\hline BANK & CHARAKTER PROGRAMU & WARUNKI REALIZACII \\
\hline BOŚ & Brak programu & - \\
\hline $\mathrm{BPH}^{*}$ & $\begin{array}{c}\text { Długoterminowy Program Motywacyjny GE dla kadry } \\
\text { menedżerskiej najwyższego szczebla. } \\
\text { Opcje na akcje GE i akcje zastrzeżone do dnia nabycia } \\
\text { uprawnień (Resticted Stock Units) }\end{array}$ & $\begin{array}{l}\text { wyniki banku } \\
\text { indywidualnych wyników pracy }\end{array}$ \\
\hline$B G \dot{Z}$ & Brak programu & - \\
\hline $\mathrm{BRE}^{\star \star *}$ & $\begin{array}{c}\text { Program motywacyjny dla Członków Zarządu Banku. } \\
\text { Możliwość objęcia obligacji z prawem pierwszeństwa } \\
\text { do objęcia akcji BRE Banku oraz objęcia akcji jednostki } \\
\text { dominującej Commerzbanku AG. }\end{array}$ & $\begin{array}{c}\text { wskaźnik ROE w Grupie BRE } \\
\text { wykonanie budżetu w nadzorowanym } \\
\text { obszarze } \\
\text { indywidualna ocena członka Zarządu } \\
\text { przez RN }\end{array}$ \\
\hline$B Z W_{B K}^{\star *}$ & $\begin{array}{l}\text { Program Motywacyjny dla członków zarządu. } \\
\text { Nabycie obligacji z prawem pierwszeństwa a następ- } \\
\text { nie nabycie po preferencyjnej cenie akcji banku. }\end{array}$ & skonsolidowany dla 3 lat EPS \\
\hline Alior Bank ${ }^{\star *}$ & $\begin{array}{l}\text { Prawo do otrzymania akcji Alior Banku bez dodatko- } \\
\text { wej płatności }\end{array}$ & $\begin{array}{l}\text { zmiana ceny akcji Banku w okresie re- } \\
\text { ferencyjnym musi przewyższać zmianę } \\
\text { wartości indeksu WIG-Banki }\end{array}$ \\
\hline Paribas Fortis* & $\begin{array}{l}\text { Program Opcji Pracowniczych dla Kadry Zarządzającej } \\
\text { organizowany przez Fortis SA/NV, opcje na akcje Fortis }\end{array}$ & brak informacji \\
\hline Kredyt Bank & brak programu & - \\
\hline DZ Polska & brak programu & - \\
\hline Bank Handlowy* & $\begin{array}{l}\text { Program świadczeń kapitałowych w formie akcji lub } \\
\text { opcji na akcje Citygroup. }\end{array}$ & brak informacji \\
\hline $\mathrm{ING}^{*}$ & $\begin{array}{l}\text { Długoterminowy System Motywacyjny ING Groep NV, } \\
\text { share option, performance share. }\end{array}$ & $\begin{array}{l}\text { porównanie TSH Grupy ING ze wskaź- } \\
\text { nikami dla podobnych instytucji finan- } \\
\text { sowych. }\end{array}$ \\
\hline Millennium & brak programu & - \\
\hline Noble Bank ${ }^{* *}$ & $\begin{array}{c}\text { Program płatności w formie akcji Noble Funds TFI } \\
\text { S.A., Program Opcji Menedżerskich }\end{array}$ & sytuacja finansowa Banku \\
\hline Nordea* & Program Wypłat Opartych o Akcje & brak informacji \\
\hline Pekao S. A. ${ }^{* * *}$ & $\begin{array}{c}\text { Długoterminowy Program Motywacyjny, opcje na akcje } \\
\text { i akcje UniCredit S.p.A. } \\
\text { Program opcji menedżerskich }\end{array}$ & brak informacji \\
\hline PKO BP & Brak programu & - \\
\hline
\end{tabular}

* programy realizowane w ramach grupy kapitałowej

** programy oparte na kapitale emitenta

*** programy realizowane w ramach grupy kapitałowej oraz oparte na kapitale emitenta Źródło: Opracowanie własne na podstawie raportów rocznych banków.

Wątpliwości również budzą warunki realizacji programów stosowane przez część banków. Występują takie sytuacje, kiedy podstawą do wypłaty wynagrodzenia są wyniki osiągane przez całą grupę kapitałową. Tymczasem po- 
winna to być przede wszystkim ocena efektów pracy osoby zajmującej stanowisko kierownicze w banku oraz wyniki banku w obszarze odpowiedzialności takiej osoby.

Warunkiem skuteczności długoterminowych programów motywacyjnych jest to, żeby korzyści, jakie otrzymują z tego tytułu osoby zarządzające spółkami stanowiły istotną część całkowitego wynagrodzenia. Liczne badania prowadzone w Stanach Zjednoczonych i krajach europejskich wskazują, iż dochody w tytułu uczestnictwa w programach opartych na własności w wielu przypadkach są dominującym składnikiem wynagrodzenia całkowitego. W Wielkiej Brytanii przeciętnie stanowią około 30\%, w Stanach Zjednoczonych dochodzą do $50 \%{ }^{13}$. W największych bankach amerykańskich, które w latach 2007-2008 przechodziły kryzys finansowy, udział dochodów z tytułu programów opcyjnych przekraczał $80 \%$ całkowitego wynagrodzenia, w tym szef Lechman Brothers w roku 2007 otrzymał w formie tzw. akcji uwarunkowanych (Restricted Stock Units) kwotę $40 \mathrm{mln}$ USD, co stanowiło 87,5\% przyznanego wynagrodzenia ${ }^{14}$.

Analiza rodzaju instrumentów motywacyjnych w przypadku polskich banków publicznych pokazuje, że ich zakres mierzony udziałem dochodów z tego tytułu w całkowitych wynagrodzeniach członków zarządów jest zdecydowanie mniejszy (tabela 2). Jedynym bankiem, dla którego występują wskaźniki podobne do tych w innych krajach europejskich jest Noble Bank. W pozostałych bankach dochody $\mathrm{z}$ akcji i opcji nie przekraczają $10 \%$ całkowitych wynagrodzeń. Nie stwierdzono również istotnych różnic jeśli chodzi o skalę tego zjawiska w okresie kryzysu - lata 2008-2009 - oraz okresie poprawy koniunktury na rynku kapitałowym - lata 2010-2012.

Tabela 2. Relacja wartości długoterminowych programów motywacyjnych do wynagrodzenia całkowitego członków zarządu (w \%)

\begin{tabular}{|c|c|c|c|c|c|}
\hline BANK & 2008 & 2009 & 2010 & 2011 & 2012 \\
\hline BOŚ & $0,0 \%$ & $0,0 \%$ & $0,0 \%$ & $0,0 \%$ & $0,0 \%$ \\
\hline BPH $^{\star}$ & $15,4 \%$ & $7,1 \%$ & $8,6 \%$ & $6,9 \%$ & $6,2 \%$ \\
\hline BGŻ & $0,0 \%$ & $0,0 \%$ & $0,0 \%$ & $0,0 \%$ & $0,0 \%$ \\
\hline BRE $^{\star \star \star}$ & $0,0 \%$ & $0,0 \%$ & $7,2 \%$ & $7,7 \%$ & $4,5 \%$ \\
\hline BZ WBK ${ }^{\star \star}$ & b.d. & b.d. & b.d. & b.d. & b.d. \\
\hline Alior Bank & b.d. & b.d. & b.d. & b.d. & b.d. \\
\hline
\end{tabular}

${ }^{13}$ M. Conyon, N. Fernandes, M. Ferreira, P. Matos, K. Murphy, The Executive Compensation Controversy: A Transatlantic Analysis, Fondazione Rodolfo De Benedetti, 2010, p. 83.

${ }_{14}$ Nestor Advisors Ltd, Governance in Crisis: A comparative case study of six US investment banks, London 2009. 


\begin{tabular}{|c|c|c|c|c|c|}
\hline BANK & 2008 & 2009 & 2010 & 2011 & 2012 \\
\hline Paribas Fortis* & $1,2 \%$ & $1,3 \%$ & $1,1 \%$ & $1,3 \%$ & $6,6 \%$ \\
\hline Kredyt Bank & $0,0 \%$ & $0,0 \%$ & $0,0 \%$ & $0,0 \%$ & $0,0 \%$ \\
\hline DZ Polska & $0,0 \%$ & $0,0 \%$ & $0,0 \%$ & $0,0 \%$ & $0,0 \%$ \\
\hline Bank Handlowy* & $5,5 \%$ & $2,4 \%$ & $4,1 \%$ & $11,9 \%$ & $7,7 \%$ \\
\hline ING* $^{*}$ & $0,0 \%$ & $0,1 \%$ & $0,5 \%$ & $0,7 \%$ & $1,9 \%$ \\
\hline Millennium $_{\text {Noble Bank* }}^{* *}$ & $0,0 \%$ & $0,0 \%$ & $0,0 \%$ & $0,0 \%$ & $0,0 \%$ \\
\hline Nordea* & $0,0 \%$ & $0,0 \%$ & $35,8 \%$ & $46,2 \%$ & $13,4 \%$ \\
\hline Pekao S. A.** & $6,3 \%$ & $6,0 \%$ & $10,1 \%$ & $3,9 \%$ & b.d. \\
\hline PKO BP & $2,9 \%$ & $3,5 \%$ & $17,0 \%$ & $16,0 \%$ & $6,8 \%$ \\
\hline
\end{tabular}

Źródło: Opracowanie własne na podstawie raportów rocznych banków.

Charakterystyczną cechą systemu kontroli nad korporacją, jaki występuje na polskim rynku kapitałowym jest wysoka koncentracja własności i kontroli. W zdecydowanej większości spółek notowanych na Giełdzie Papierów Wartościowych w Warszawie występuje akcjonariusz dominujący, który dysponuje kontrolnym pakietem akcji i głosów ${ }^{15}$. Pozycja największych akcjonariuszy jest jeszcze silniejsza w spółkach sektora bankowego. Dla właścicieli 1 pakietu akcji mediana udziału w kapitale akcyjnym wynosi $75 \%$. Są to przede wszystkim zagraniczni inwestorzy branżowi, którzy kontrolują 13 z 16 banków publicznych. Kolejne pakiety są znacznie mniejsze i w większości banków, poza dominującym akcjonariuszem, nie ma innych posiadających więcej niż 5\% akcji.

Tak silna pozycja akcjonariuszy większościowych może być punktem wyjścia do próby wyjaśnienia skali i rodzaju długookresowych programów motywacyjnych stosowanych w polskich bankach publicznych. Badania prowadzone przez Ferrariniego i in. wykazały, że poziom wynagradzania kadry kierowniczej różni się istotnie między krajami. Można zaobserwować np. znacząco większe wynagrodzenia w krajach anglosaskich i mniejszy ich poziom w krajach nordyckich ${ }^{16}$. W innym badaniu zaobserwowano, że korporacje $z$ większym udziałem amerykańskich inwestorów instytucjonalnych $\mathrm{w}$ akcjonariacie adoptują amerykańskie wzorce w polityce wynagradzania kadry kierowniczej ${ }^{17}$.

15 P. Urbanek, Rynek kontroli nad korporacja w warunkach zamkniętego modelu kontroli na przyktadzie polskich spótek publicznych, „Zeszyty Naukowe”, Polskie Towarzystwo Ekonomiczne, Nr 9/2011.

${ }^{16}$ R. Barontini, S. Bozzi, G. Ferrarini, M. Ungureanu, Directors' Remuneration Before and After the Crisis: Measuring the Impact of Reforms in Europe, mimeo, 2013.

17 N. Fernandes, M. Ferreira, P. Matos, K. Murphy, Are US CEOs Paid More? An International Perspective, SSRN Paper, 2012. 
Tabela 3. Długoterminowe programy motywacyjne (LTIP) a kraj pochodzenia akcjonariusza większościowego

\begin{tabular}{|c|c|c|c|c|}
\hline \multirow[b]{2}{*}{ WYSZCZEGÓLNIENIE } & \multicolumn{4}{|c|}{ AKCIONARIUSZ WIĘKSZOŚCIOWY } \\
\hline & $\begin{array}{l}\text { USA, UK, IR- } \\
\text { LANDIA }\end{array}$ & EUROPA PŁD. & EUROPA PN. & POLSKA \\
\hline Brak LTIP & $\begin{array}{c}0 \\
0 \%\end{array}$ & $\begin{array}{c}1 \\
20 \%\end{array}$ & $\begin{array}{c}3 \\
50 \%\end{array}$ & $\begin{array}{c}2 \\
66,7 \%\end{array}$ \\
\hline LTIP w ramach grupy kapitałowej & $\begin{array}{c}2 \\
100 \%\end{array}$ & $\begin{array}{c}1 \\
20 \%\end{array}$ & $\begin{array}{c}2 \\
33,3 \%\end{array}$ & $\begin{array}{c}0 \\
0 \%\end{array}$ \\
\hline LTIP oparte na kapitale emitenta & $\begin{array}{c}0 \\
0 \%\end{array}$ & $\begin{array}{c}3 \\
60 \%\end{array}$ & $\begin{array}{c}1 \\
16,7 \% \\
\end{array}$ & $\begin{array}{c}1 \\
33,3 \% \\
\end{array}$ \\
\hline RAZEM & $\begin{array}{c}2 \\
100 \%\end{array}$ & $\begin{array}{c}5 \\
100 \%\end{array}$ & $\begin{array}{c}6 \\
100 \%\end{array}$ & $\begin{array}{c}3 \\
100 \%\end{array}$ \\
\hline
\end{tabular}

Źródło: Opracowanie własne na podstawie raportów rocznych banków.

Dla potrzeb oceny badane banki zostały podzielone na cztery grupy ze względu na kraj pochodzenia inwestora dominującego: USA, Wielka Brytania i Irlandia, Europa Południowa, Europa Północna oraz Polska. Otrzymane wyniki nie wskazują jednoznacznie na występowanie prawidłowości świadczących o podobnych praktykach związanych $z$ długoterminowymi programami motywacyjnymi w ramach danej grupy krajów. Dwa banki kontrolowane przez inwestora anglosaskiego stosują programy w ramach grupy kapitałowej. W przypadku inwestorów z Europy Południowej 60\% wykorzystuje programy oparte na kapitale emitenta. $\mathrm{Na}$ trzy banki kontrolowane przez podmioty krajowe w dwóch tego typu rozwiązania nie są stosowane.

Kontrakt oparty na wynikach jest mechanizmem łagodzenia problemu agencji, w sytuacji, kiedy bezpośredni monitoring prowadzony przez akcjonariuszy nie jest możliwy lub jest zbyt kosztowny. Można założyć, że skala asymetrii informacji między akcjonariuszami a menedżerami skłaniająca do stosowania tego mechanizmu rośnie wraz ze wzrostem skali prowadzonej przez bank działalności. To zaś może wskazywać, ze należałoby oczekiwać, iż większe banki będą częściej sięgać do długoterminowych programów motywacyjnych. Dane przedstawione w tabeli 4 potwierdzają ten wniosek. W bankach wykorzystujących programy motywacyjne oparte na kapitale emitenta przeciętna wartość aktywów w badanym okresie mierzona medianą i średnią arytmetyczną jest wyższa niż w pozostałych grupach banków. 
Tabela 4. Długoterminowe programy motywacyjne (LTIP) a wybrane wskaźniki ekonomiczne

\begin{tabular}{|c|c|c|c|c|c|}
\hline WYSZCZEGóLNIENIE & & AKTYWA (MLN ZZ) & ROE & SHR & RYZYKO \\
\hline \multirow{2}{*}{ Brak LTIP } & mediana & 38032 & $6,5 \%$ & $0,7 \%$ & $0,72 \%$ \\
\cline { 2 - 6 } & średnia & 51751 & $7,5 \%$ & $-5,8 \%$ & $0,83 \%$ \\
\hline \multirow{2}{*}{ LTIP W ramach grupy kapitałowej } & mediana & 35215 & $-3,0 \%$ & $11,4 \%$ & $0,83 \%$ \\
\cline { 2 - 6 } & średnia & 37427 & $6,9 \%$ & $4,3 \%$ & $1,04 \%$ \\
\hline \multirow{2}{*}{ LTIP oparte na kapitale emitenta } & mediana & 57838 & $10,7 \%$ & $13,2 \%$ & $1,26 \%$ \\
\cline { 2 - 6 } & średnia & 68420 & $14,4 \%$ & $5,2 \%$ & $1,19 \%$ \\
\hline \multirow{2}{*}{ RAZEM } & mediana & 41003 & $7,3 \%$ & $10,9 \%$ & $0,84 \%$ \\
\cline { 2 - 6 } & średnia & 52484 & $9,5 \%$ & $0,8 \%$ & $1,04 \%$ \\
\hline
\end{tabular}

Źródło: Opracowanie własne na podstawie raportów rocznych banków.

Porównanie innych wskaźników ekonomicznych charakteryzujących wyodrębnione trzy grupy banków również potwierdza wnioski, które mogą być formułowane na podstawie teorii agencji. W trzeciej grupie banków stosujących programy partycypacji we własności przeciętna rentowność mierzona wskaźnikami ROE i SHR jest prawie dwukrotnie wyższa nie w pozostałych bankach. Konsekwencją wykorzystywania bardziej agresywnych systemów motywowania kadry kierowniczej powinno być wyższe ryzyko. Otrzymane rezultaty potwierdzają tę hipotezę. Najwyższy poziom ryzyka mierzonego udziałem odpisów na rezerwy w wartości portfela kredytowego ponownie występuje w bankach wykorzystujących długoterminowe programy wynagradzania oparte na kapitale własnym.

\section{ZAKOŃCZENIE}

Celem artykułu była ocena programów partycypacji menedżerów we własności stosowanych w bankach publicznych w Polsce. Rozwiązanie to jest powszechnie traktowane jako jeden $\mathrm{z}$ instrumentów nadzoru korporacyjnego, który łagodząc tzw. problem agenta zbliża interesy akcjonariuszy i menedżerów. Doświadczenia wyniesione $\mathrm{z}$ ostatniego kryzysu finansowego mogą skłaniać do formułowania odmiennych wniosków. Banki, które w szerszym zakresie sięgały do tego rozwiązania, w czasie kryzysu osiągały gorsze wyniki finansowe. Może to sugerować, że narzędzie, które w swoim założeniu miało służyć kreowaniu wartości dla akcjonariuszy, w praktyce okazało się metodą kreowania korzyści dla kadry kierowniczej, nie zabezpieczającą banków i akcjonariuszy przed ogromnymi stratami w okresie załamania koniunktury na rynkach kapitałowych. 
Analiza programów partycypacji we własności w bankach notowanych na GPW w Warszawie pokazuje, że w polskich bankach publicznych skala wykorzystania tej metody wynagradzania kadry kierowniczej jest zdecydowanie mniejsza niż w innych krajach. Zaledwie co trzeci bank stosuje programy oparte na tytułach własności we własnym kapitale. Zarazem dla tych banków można zaobserwować lepsze od przeciętnych wyniki finansowe. W tym kontekście nowe regulacje wprowadzone od roku 2011 przez Komisję Nadzoru Finansowego, zobowiązujące banki publiczne do szerszego stosowania tych instrumentów motywowania kadry kierowniczej można uznać za właściwy krok w kierunku usprawnienia standardów ładu korporacyjnego na polskim rynku kapitałowym.

\section{BIBLIOGRAFIA}

Barontini R., Bozzi S., Ferrarini G., Ungureanu M., Directors' Remuneration Before and After the Crisis: Measuring the Impact of Reforms in Europe, mimeo, 2013.

Conyon M., Fernandes N., Ferreira M., Matos P., Murphy K., The Executive Compensation Controversy: A Transatlantic Analysis, Fondazione Rodolfo De Benedetti, 2010.

Directive 2010/76/EU of the European Parliament and of the Council of 24 November 2010 amending directives 2006/48/EC and 2006/49/EC as regards capital requirements for the trading book and for re-securitizations, and the supervisory review of remuneration policies, Dz.U. UE L 329/3/2010.

Fernandes N., Ferreira M., Matos P., Murphy K., Are US CEOs Paid More? An International Perspective, SSRN Paper, 2012, http://dx.doi.org/10.2139/ssrn.1341639.

Jensen M.C., Meckling W.H., Theory of the Firm: Managerial Behavior, Agency Costs and Ownership Structure, "Journal of Financial Economics”, No 3/1976, http:// dx.doi.org/10.1016/0304-405x(76)90026-x.

Komisja Europejska, Zielona ksiega. Ead korporacyjny w instytucjach finansowych oraz polityka wynagrodzeń, Bruksela 2010.

Komisja Nadzoru Finansowego, Interpretacja uchwał KNF w zakresie polityki zmiennych składników wynagrodzeń osób zajmujących stanowiska kierownicze w ban$\mathrm{ku}, 23.12 .2011$.

Kose J., Yiming Q. Incentive Features in CEO Compensation in the Banking Industry, „Economic Policy Review”, April 2003.

Marcinkowska M., Jak wzmocnić wtadztwo korporacyjne w bankach?, [w:] P. Urbanek (red.), Nadzór korporacyjny w warunkach kryzysu gospodarczego, Wydawnictwo Uniwersytetu Łódzkiego, Łódź 2010.

Międzynarodowy Standard Sprawozdawczości Finansowej 2, Ptatności w formie akcji wtasnych.

Mulbert P.O., Corporate governance of banks after the financial crisis - Theory, evidence, reforms, CEGI Working Paper Series in Law, No. 151/2010, http://dx.doi. org/10.2139/ssrn.1448118. 
Nestor Advisors Ltd, Governance in Crisis: A comparative case study of six US investment banks, London 2009.

Rozporzadzeniu Ministra Finansów z dnia 19 lutego 2009 r. w sprawie informacji bieżqcych $i$ okresowych przekazywanych przez emitentów papierów wartościowych oraz warunków uznawania za równoważne informacji wymaganych przepisami prawa państwa niebędacego państwem cztonkowskim, Dz. U., nr 33, poz. 259.

Uchwata Komisji Nadzoru Finansowego z dnia 4 pazdziernika 2011 roku w sprawie szczegótowych zasad funkcjonowania systemu zarzadzania ryzykiem i systemu kontroli wewnętrznej oraz szczegótowych warunków szacowania przez banki kapitatu wewnętrznego $i$ dokonywania przegladów procesu szacowania i utrzymywania kapitatu wewnętrznego oraz zasad ustalania polityki zmiennych sktadników wynagrodzeń osób zajmujacych stanowiska kierownicze w banku, $\mathrm{Nr}$ 258/2011.

Urbanek P., Rynek kontroli nad korporacja w warunkach zamkniętego modelu kontroli na przyktadzie polskich spótek publicznych, „Zeszyty Naukowe”, Polskie Towarzystwo Ekonomiczne, Nr 9/2011.

Ustawa z dnia 28 kwietnia 2011 roku z zmianie ustawy - Prawo bankowe, ustawy o obrocie instrumentami finansowymi oraz ustawy o nadzorze nad rynkiem finansowym, Dz. U. z 2011 r. Nr 131, poz. 763.

Zalecenie Komisji z dnia 30 kwietnia 2009 r. w sprawie polityki wynagrodzeń w sektorze ustug finansowych 2009/384/WE, Dz. U. UE L 120/22. 